\title{
ІДЕНТИФІКАЦІЯ СТЕЙКХОЛДЕРІВ ОРГАНІЗАЦІЙНИХ ПРОЕКТІВ У СФЕРІ ОБСЛУГОВУВАННЯ ЛІТАКІВ
}

\author{
Мельниченко O.I., кандидат технічних наук, професор, Національний транспортний \\ університет, Київ, Україна, melnichenko@ntu.edu.ua, orcid.org/0000-0001-9694-9824 \\ Сепеда Гуаман Д.Ф., Університет «КРОК», Київ, Україна, ferchoevol2@hotmail.com, \\ orcid.org/0000-0003-0791-6532 \\ Бєлова O.I., кандидат економічних наук, доцент, Університет «КРОК», Київ, Україна, \\ belovaelenag@gmail.com, orcid.org/0000-0001-9359-6947
}

\section{IDENTIFICATION OF STAKEHOLDERS OF ORGANIZATIONAL PROJECTS IN THE FIELD OF MAINTENANCE OF AIRCRAFT}

\author{
Melnichenko O.I., Ph.D., Professor, National Transport University, Kyiv, Ukraine, \\ melnichenko@ntu.edu.ua, orcid.org/0000-0001-9694-9824 \\ Cepeda Guaman D.F., University "KROK", Kyiv, Ukraine, ferchoevol2@hotmail.com, \\ orcid.org/0000-0003-0791-6532 \\ Bielova O.I., Ph.D., Associate Professor, University "KROK”, Ukraine, belovaelenag@gmail.com, \\ orcid.org/0000-0001-9359-6947
}

\section{ИДЕНТИФИКАЦИЯ СТЕЙКХОЛДЕРОВ ОРГАНИЗАЦИОННЫХ ПРОЕКТОВ В СФЕРЕ ОБСЛУЖИВАНИЯ САМОЛЕТОВ}

Мельниченко А.И., кандидат технических наук, профессор, Национальный транспортный университет, Киев, Украина, melnichenko@ntu.edu.ua, orcid.org/0000-0001-9694-9824

Сепеда Гуаман Д.Ф., Университет «КРОК», Киев, Украина, ferchoevol2@hotmail.com, orcid.org/0000-0003-0791-6532

Белова Е.И., кандидат экономических наук, доцент, Университет «КРОК», Киев, Украина, belovaelenag@gmail.com, orcid.org/0000-0001-9359-6947

\section{Постановка проблеми.}

Сучасний стан розвитку галузі літакобудування у світі вимагає від виробників авіаційної техніки постійного іï удосконалення з метою підвищення якості надання транспортних послуг. Для цього у світовому товаристві постійно удосконалюються міжнародні норми, вимоги та стандарти щодо проектування та виготовлення літаків. Новітня авіаційна техніка також потребує відповідного обслуговування після іiі введення до експлуатації, яке повинно забезпечувати у подальшому якість надання транспортних послуг. Сьогодні більшість виробників самостійно здійснюють обслуговування літаків як на території заводів, так і у аеропортах світу. Це призводить до того, що технічне обслуговування необхідно передавати іншим компаніям, які будуть надавати цю послугу у аеропортах та на спеціально обладнаних майданчиках поза їх межами.

На цей час подібних компаній у світі не існує, тому є необхідність розвинення цього сегменту ринку шляхом створення нових підприємств, а також запровадження проектного підходу не тільки у літакобудуванні, а ще й у сфері їх технічного обслуговування.

Аналіз останніх досліджень і публікацій.

Науковці всього світу приділяють багато уваги застосуванню методології управління проектами у різних сферах промисловості, зокрема спрямованих на створення нових підприємств, їх розвиток та удосконалення, зокрема у роботах Бегун А. П. розглянуто та запропоновано сформувати портфель проектів на основі аналізу стратегій діяльності підприємства; Бек В. О. запропоновано моделювання нових організаційних структур управління проектами; Бондарчук О. В. розглянуто мультипроектне управління реструктуризацією та розвитком організацій в динамічному середовищі; Вайсмана В. О. запропоновані моделі, методи і механізми створення і функціонування проектнокерованої організації [1]; Вітюніна Є. Ю. розроблені методичні основи управління змістом та цілями в проектах реструктуризації на прикладі комунальної теплоенергетики; Малєєвої О. В. розглянуті питання розвитку підприємства та запропоновані шляхи удосконалення системи управління ними; 
Мазорчук М. С. розглянуто розвиток виробництва з урахуванням залучення додаткових інвестицій; Чернова С. К. запропоновані ефективні організаційні структури в управлінні програмами розвитку наукомістких підприємств [2].

Також, науковці розглядали питання розвитку, ремонту та удосконалення техніки, а також надання послуг із обслуговування, наприклад, у роботах Годованюка П. Д. розроблено моделі, алгоритми та стратегії в проектах вдосконалення дорожньо-будівельної техніки [3]; Маркова О. Д. та Низковолосова В. В. наведено процес формування послуги автосервісу та алгоритм ії проектування на основі моделі Зайтемля [4]; Сляднєва О. В. запропоновано управління проектами створення модифікацій пасажирських і транспортних літаків в умовах ринкової економіки; Татомира А. В. Запропоновано узгодження конфігурацій проектів сервісних та обслуговуваних систем (стосовно електрозабезпечення сільськогосподарських підприємств за використання енергії вітру); Чимшира В. I. розроблено та реалізовано проектно-орієнтований підхід щодо керування процесами функціонування суднових технічних засобів; Щеголь В. А. розглянуто управління проектами створення космічної техніки нового покоління на основі компонентного підходу.

Управлінню проектами у галузі літакобудування також присвячено багато праць вчених, зокрема, Бабак I. М. проведений аналіз проектів створення нової техніки з урахуванням причиннонаслідкових зв'язків факторів ризику; Дружиніним С. А. запропонований ризик-орієнтований підхід до управління ресурсами проектів і програм розвитку техніки; Емадом А. Абдуль Рета розглянуто управління програмою розвитку авіаційної техніки [5]; Крахмальовою Т. І. запропоновано управління інтелектуальною власністю у проектах створення авіаційної техніки; Погудіною О. К. було розглянуто формування і контроль в управлінні якістю і змістом проектів створення складної техніки; Сляднєвим О. В. запропоновано управління проектами створення модифікації пасажирських і транспортних літаків в умовах ринкової економіки [6]; Яшиною О. С. проведено моделювання динаміки фінансування проектів та програм створення нової техніки на основі детермінованого та імовірністного подання.

Крім того, є роботи Бушуєва С. Д. [7], Данченко О. Б. [8], Рейтера С., Фрімена Е. [9], Чумаченка I. В. [10] стосовно ідентифікації стейкхолдерів проектів та оцінки їх впливу на проекти, а також управління ними.

Також, автором у роботах [11] більш детально були розглянуті організаційні проекти у сфері обслуговування літаків та в [12] розглянуті особливості управління ними.

Із проведеного аналізу наукових праць видно, що на цей час залишається поза увагою питання управління згаданими проектами в частині управління стейкхолдерами цих проектів із урахуванням їх позитивного або негативного впливу на реалізацію організаційних проектів у сфері обслуговування літаків.

Швидкі темпи розвитку галузі літакобудування на сьогоднішній день вимагають від компанійвиробників удосконалення авіаційної техніки, що у свою чергу призводить до потреби своєчасного оновлення матеріально-технічної бази та обладнання для забезпечення якісного надання послуг із їх технічного обслуговування будь-де за межами виробничих потужностей заводів. Якісне технічне обслуговування повітряних суден у подальшому може забезпечити задоволення очікувань стейкхолдерів організаційних проектів у сфері обслуговування літаків. Крім того, для задоволення потреб стейкхолдерів керівникам цих проектів необхідно взяти до уваги ризики, що можуть бути пов'язані із ними та мати, як позитивні, так і негативні наслідки для цих проектів. Тому необхідно враховувати мінливість зовнішнього та внутрішнього оточення організаційних проектів у сфері обслуговування літаків, відношення самих стейкхолдерів до цих проектів можуть стати загрозою для успішної реалізації проекту та забезпечення цінностей усіх його стейкхолдерів.

Метою дослідження $є$ виділення стейкхолдерів організаційного проекту, проведення їх ідентифікації та оцінки.

Забезпечення своєчасної, якісної та у рамках виділеного бюджету реалізації будь-якого проекту вимагає від його керівника відповідального та зваженого планування, зокрема проведення аналізу стейкхолдерів проекту та виявлення ризиків, що можуть бути пов'язані із їх діяльністю або бездіяльністю [13]. У сучасному світі науковці приділяють багато уваги ідентифікації, аналізу й управлінню стейхолдерами, а також ними проведено багато досліджень у цій сфері тому, що цей об’єкт має дуже сильний вплив на проект. Він може як покращити результат проекту, так і повністю дискредитувати його, тим самим завершити проект без досягнення поставленої мети $[9,14]$.

Основоположним дослідженням зацікавлених осіб $\epsilon$ теорія стейкхолдерів, яка почала формуватися ще з 60-х років XX-ст. Перше уявлення полягало у тому, що компанія - це система, яка має вплив та зазнає впливу з боку свого оточення: постачальників, споживачів, персоналу акціонерів 
тощо [9,14]. У середині 70-х років XX ст. Рассел Акофф продовжив розвиток цієї теорії та запропонував розширити кількість стейкхолдерів до наступного покоління $[9,15,16]$. Однак сучасне уявлення теорії стейкхолдерів склалося з середини 80 -х років завдяки Едварду Фрімену, саме його ідея полягала у тому, що внутрішне та зовнішне уявлення фірми - це її зацікавлені сторони, чиї інтереси та вимоги повинні бути задоволені $[9,14]$.

Після виникнення теорії було розроблено два важливих стандарти:

-ISO 26000:2010 Guidance on social responsibility (Керівництво із соціальної відповідальності) [15], яке містить у собі рекомендації із соціальної відповідальності компанії;

-AA1000 Stakeholder Engagement Standard (SES) 2018 (Стандарт взаємодії із зацікавленими сторонами) $[13,16]$, розроблений Institute of Social and Ethical Account Ability - це загальноприйнятна нормативна база для планування, виконання, оцінки, інформування та нефінансової аудиторської перевірки якості взаємодії із зацікавленими сторонами у процесі звітності та підпорядкованості організацій, у галузі ефективного муніципального управління. Обидва стандарти $[14,15]$ містять достатньо серйозні рекомендації, а AA1000SES [16] має всередині повну покрокову інструкцію із залучення стейкхолдерів у процеси діяльності компанії. 3 точки зору проектного підходу [14] керівник проекту та його команда повинна формулювати перелік зацікавлених сторін проекту 3 самого початку проекту, тобто зі стадії ініціації проекту, та постійно працювати із ним шляхом внесення коректив до нього. Крім того, для зручності користування ним виникає необхідність його систематизації за певним критерієм або критеріями $[9,13,14]$. Зацікавлені сторони організаційних проектів у сфері обслуговування літаків можна визначити наступним набором елементів, який наведемо у вигляді табл. 1.

Таблиця 1 - Перелік стейкхолдерів організаційних проектів у сфері обслуговування літаків

Table 1 - List of stakeholders of organizational projects in the field of aircraft maintenance

\begin{tabular}{|c|l|l|}
\hline $\begin{array}{c}\text { № } \\
\text { п/п }\end{array}$ & $\begin{array}{c}\text { Стейкхолдер/група } \\
\text { стейкхолдерів }\end{array}$ & \multicolumn{1}{|c|}{ Роль } \\
\hline 1 & 2 & \multicolumn{1}{|c|}{3} \\
\hline 1 & Менеджер проекту & $\begin{array}{l}\text { Фізична або юридична особа, яка відповідає за планування та } \\
\text { реалізацію проекту у сфері обслуговування літаків }\end{array}$ \\
\hline 2 & Команда проекту & $\begin{array}{l}\text { Група людей, яка виконує організаційний проект у сфері } \\
\text { обслуговування літаків }\end{array}$ \\
\hline 3 & Ініціатор & $\begin{array}{l}\text { Особа, яка дала ідею організаційного проекту у сфері обслуговування } \\
\text { літаків, а також особа, через кого вона була отримана - заводи- } \\
\text { виробники авіаційної техніки, авіакомпанії, аеропорти }\end{array}$ \\
\hline 4 & Замовник & $\begin{array}{l}\text { Особа, яка дала замовлення на створення продукту організаційного } \\
\text { проекту у сфері обслуговування літаків - заводи-виробники авіаційної } \\
\text { техніки, авіакомпанії, аеропорти }\end{array}$ \\
\hline 5 & Власник & $\begin{array}{l}\text { Особа, яка буде володіти правами на продукт організаційного проекту } \\
\text { у сфері обслуговування літаків після його введення до експлуатації - } \\
\text { компанія, яка буде здійснювати обслуговування }\end{array}$ \\
\hline 6 & Інвестор & $\begin{array}{l}\text { Особа, яка буде фінансувати організаційний проект у сфері } \\
\text { обслуговування літаків - банки, міжнародні фінансові установи, } \\
\text { заводи-виробники авіаційної техніки, авіакомпанії, аеропорти }\end{array}$ \\
\hline 7 & $\begin{array}{l}\text { Конкуренти основних } \\
\text { учасників проекту }\end{array}$ & $\begin{array}{l}\text { Особи, які можуть впливати (позитивно/негативно) на реалізацію } \\
\text { організаційного проекту у сфері обслуговування літаків або діяльність } \\
\text { команди цього проекту - заводи-виробники авіаційної техніки, } \\
\text { авіакомпанії, аеропорти }\end{array}$ \\
\hline $\begin{array}{l}\text { Державні та місцеві органи влади, які можуть бути зацікавлені або } \\
\text { незацікавлені у створенні продукту організаційного проекту у сфері } \\
\text { обслуговування літаків - міжнародні організації, державні та місцеві } \\
\text { органи влади }\end{array}$ \\
\hline 19 влади
\end{tabular}


Продовження таблиці 1

Continuation of Table 1

\begin{tabular}{|c|l|l|}
\hline 1 & \multicolumn{1}{|c|}{2} & \multicolumn{1}{|c|}{3} \\
\hline 9 & Ліцензіари & $\begin{array}{l}\text { Державні або приватні організації, які видають дозволи на певні види } \\
\text { ліцензованої діяльності - міжнародні авіаційні об'єднання }\end{array}$ \\
\hline 10 & $\begin{array}{l}\text { Громадські групи та } \\
\text { організації }\end{array}$ & $\begin{array}{l}\text { Особи, які можуть сприяти у проведені рекламної кампанії із показу } \\
\text { продукту організаційного проекту у сфері обслуговування літаків, } \\
\text { здаванні у оренду приміщень (боксів, ангарів) - рекламні та } \\
\text { посередницькі компанії }\end{array}$ \\
\hline 11 & $\begin{array}{l}\text { Підрядники/постачаль } \\
\text {-ники }\end{array}$ & $\begin{array}{l}\text { Особи, які надають трудові, матеріальні та фінансові ресурси для } \\
\text { реалізації організаційного проекту у сфері обслуговування літаків - } \\
\text { компанії, що здійснюють обслуговування авіапідприємств, надають } \\
\text { послуги кейтерінгу або бортового харчування, виробники обладнання, } \\
\text { запасних частин, засобів зв’язку та навігації, постачальники паливо- } \\
\text { мастильних матеріалів }\end{array}$ \\
\hline 12 & $\begin{array}{l}\text { Інші зацікавлені } \\
\text { сторони }\end{array}$ & $\begin{array}{l}\text { Інші особи, які можуть як позитивно, так і негативно впливати на } \\
\text { організаційний проект у сфері обслуговування літаків }\end{array}$ \\
\hline 13 & $\begin{array}{l}\text { Споживачі кінцевої } \\
\text { продукції }\end{array}$ & $\begin{array}{l}\text { Заводи-виробники авіаційної техніки, авіакомпанії, аеропорти, } \\
\text { пасажири }\end{array}$ \\
\hline
\end{tabular}

Із табл. 1 видно, які стейкхолдери у загальному вигляді можуть впливати на організаційний проект у сфері обслуговування літаків.

У якості початкової стадії роботи із стейкхолдерами та при використанні методологічного інструментарію у галузі відпрацювання методології взаємодії між стейкхолдерами різних рівнів, що мають різні інтереси та цінності, пропонується ідентифікувати та згрупувати всіх стейкхолдерів $[9,13,17]$. До першої групи входять як безпосередні учасники проекту (керівник проекту, команда проекту, інвестор, громадські групи та організації, підрядники/постачальники), так і споживачі результату проекту (ініціатор, замовник, власник, споживачі кінцевої продукції). До другої - ті, кого проект безпосередньо не стосується, але хто зможе на нього дуже суттєво вплинути (конкуренти основних учасників проекту, органи влади, ліцензіари, інші зацікавлені сторони). Для ідентифікації пропонується зробити вхідну оціночну карту кожного стейкхолдера окремо. Побудована на початковому етапі ідентифікації зацікавлених сторін карта стейкхолдерів, $\epsilon$ первинним плановим документом, та у процесі виконання проекту буде змінюватися. Матриця зацікавлених сторін являє собою інструмент, який більш за все підходить для адекватної ідентифікації стейкхолдерів. Вона надає суб'єктивну оцінку ступеня підтримки/протидії або сили впливу, оскільки у подальшому буде видно, що нульові значення можуть бути тригерами ризиків, що виходять із проектного оточення $[9,13,16]$. Оцінку ступеня підтримки/протидії або сили впливу стейкхолдерів на організаційний проект у сфері обслуговування літаків наведемо у вигляді табл. 2.

Таблиця 2 - Оцінка ступеня підтримки/протидії або сили впливу стейкхолдерів на проект

Table 2 - Estimation of the degree of support/counteraction or force of influence of Stakeholders on the Project

\begin{tabular}{|c|l|c|c|}
\hline $\begin{array}{c}\text { № } \\
\text { п/п }\end{array}$ & \multicolumn{1}{|c|}{ Стейкхолдер/група стейкхолдерів } & $\begin{array}{c}\text { Ступінь } \\
\text { підтримки/протидії }\end{array}$ & Сила впливу \\
\hline 1 & \multicolumn{1}{|c|}{2} & 3 & 4 \\
\hline 1 & Менеджер проекту & 3 & 4 \\
\hline 2 & Команда проекту & 3 & 3 \\
\hline 3 & Ініціатор & 4 & 3 \\
\hline 4 & Замовник & 3 & 3 \\
\hline 5 & Власник & 2 & 2 \\
\hline 6 & Інвестор & 5 & 4 \\
\hline 7 & Конкуренти основних учасників проекту & -2 & 3 \\
\hline
\end{tabular}


Продовження таблиці 2

Continuation of Table 2

\begin{tabular}{|c|l|c|c|}
\hline 1 & \multicolumn{1}{|c|}{2} & 3 & 4 \\
\hline 8 & Органи влади & -1 & 3 \\
\hline 9 & Ліцензіари & -3 & 4 \\
\hline 10 & Громадські групи та організації & -5 & 2 \\
\hline 11 & Підрядники/постачальники & 3 & 3 \\
\hline 12 & Інші зацікавлені сторони & -2 & 2 \\
\hline 13 & Споживачі кінцевої продукції & 5 & 3 \\
\hline
\end{tabular}

Виходячи із даних наведених у табл. 2 можна побудувати матрицю стейкхолдерів організаційного проекту у сфері обслуговування літаків та наведемо її на рис. 1 [13,16,18].

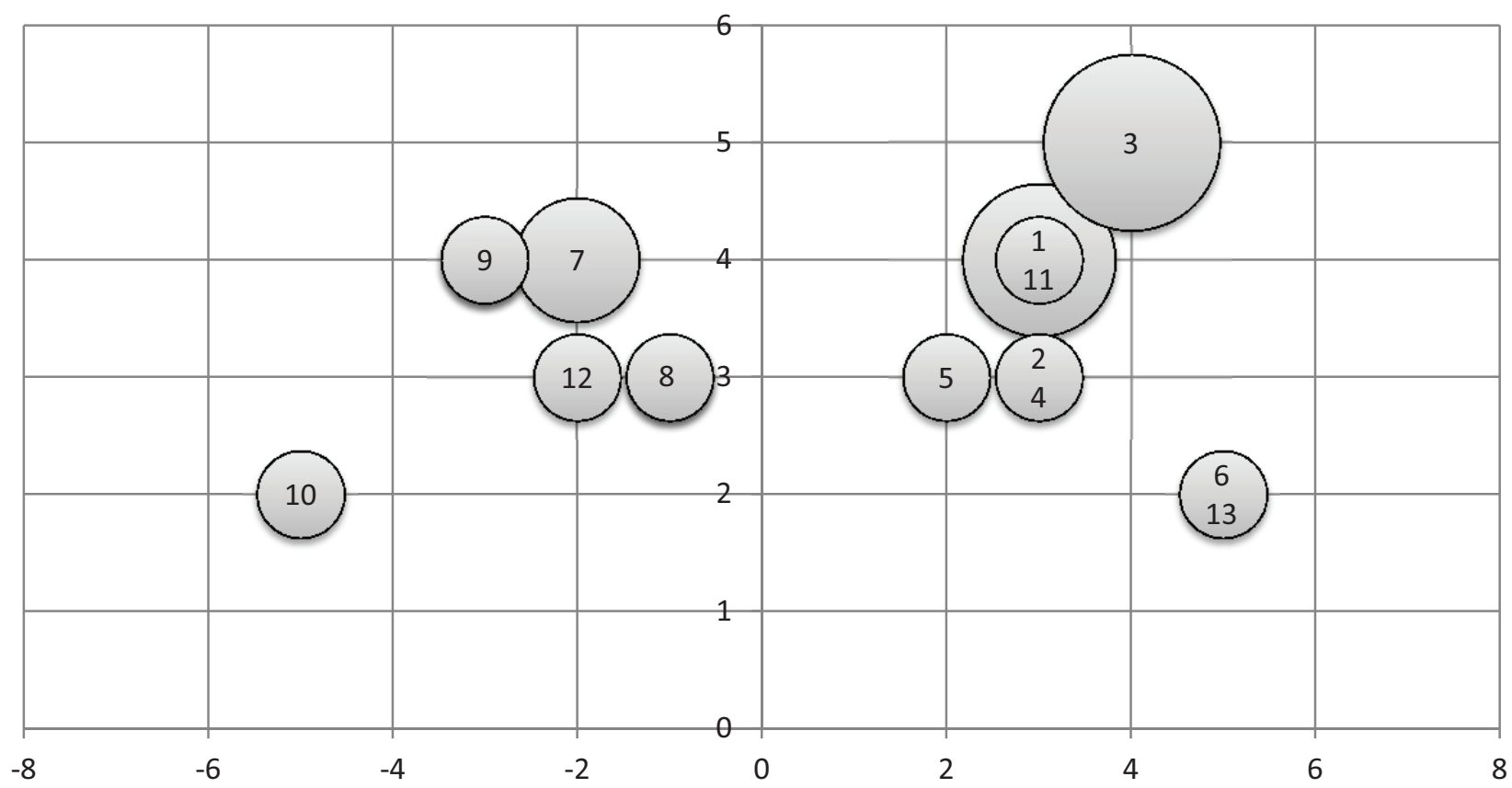

Рисунок 1 - Матриця стейкхолдерів організаційного проекту у сфері обслуговування літаків

Figure 1 - The Matrix of Stakeholders of the Organizational Project in the Field of Aircraft Maintenance

Якщо рис. 1 умовно поділити на чотири рівні частини, то можна зробити наступні висновки:

- у правому верхньому квадраті знаходяться ті, хто дійсно зацікавлений у проекті - керівник проекту, ініціатор, підрядники/постачальники;

- у правому нижньому квадраті - ті, хто на хід проекту істотного впливу не мають, але самому проекту раді й чекають від нього позитивних змін - команда проекту, замовник, власник, інвестор, споживачі кінцевої продукції;

- у лівому верхньому квадраті - ті, хто проект дуже не задоволені проектом та готові зробити все, щоб його не було - конкуренти основних учасників проекту, ліцензіари;

- у лівому нижньому квадраті - ті, кому проект не подобається, але влади щось змінити у них немає - органи влади, громадські групи та організації, інші зацікавлені сторони.

Після визначення переліку стейкхолдерів необхідно описати їх інтереси. Для цього необхідно керуватися як власними думками керівника проекту та членів його команди, так і провести опитування самих стейкхолдерів, що $є$ самим найкращим варіантом. На цьому етапі також знадобиться інформація про завершені проекти у літакобудівній галузі та про їх оточення (про компанії та про те, як у них прийнято працювати).

В залежності від зацікавленості у проекті, стейкхолдери можуть бути активами проекту або його проблемами. Обставинами, що приводять до зниження ефективності взаємодії, є недостатня та не перевірена інформація про проект, відсутність знань у галузі управління проектами й специфіки 
проекту, а також інфраструктура, фінанси, різниця у політичних поглядах, соціально-культурний контекст. Відповідно до стандарту AA1000SES [5] взаємодії із зацікавленими сторонами, «при визначені стейкхолдерів необхідно враховувати такі метрики, як рівень відповідальності, ступінь впливу, ступінь близькості, ступінь залежності». Результати аналізу інтересів стейкхолдерів організаційного проекту у сфері обслуговування літаків наведемо у вигляді табл. 3.

Таблиця 3 - Аналіз інтересів стейкхолдерів організаційних проектів у сфері обслуговування літаків

Table 3 - Analysis of the interests of Stakeholders of Organizational Projects in the field of Aircraft Maintenance

\begin{tabular}{|c|c|c|c|}
\hline \multirow{2}{*}{$\begin{array}{c}\text { Стейкхолдер/ } \\
\text { група } \\
\text { стейкхолдерів }\end{array}$} & \multirow[t]{2}{*}{ Iнтерес } & \multicolumn{2}{|c|}{ Впливи на проект } \\
\hline & & негативний & позитивний \\
\hline 1 & 2 & 3 & 4 \\
\hline $\begin{array}{l}\text { Менеджер } \\
\text { проекту }\end{array}$ & $\begin{array}{l}\text { Якісне та своєчасне } \\
\text { виконання проекту } \\
\text { відповідно до } \\
\text { встановлених вимог }\end{array}$ & $\begin{array}{l}\text { Можливість затримки та } \\
\text { коригування основних } \\
\text { параметрів при реалізації } \\
\text { проекту. } \\
\text { Гнучкість замовника } \\
\text { (ініціатора, власника), яка } \\
\text { може призвести до } \\
\text { додаткових правок та змін }\end{array}$ & $\begin{array}{l}\text { Максимальне слідування } \\
\text { технічним вимогам, для } \\
\text { виключення зайвого } \\
\text { втручання замовника } \\
\text { (ініціатора, власника). } \\
\text { Самостійна пропозиція нових } \\
\text { ідей для проекту. } \\
\text { Попереднє обговорення } \\
\text { бажаних коригувань з метою } \\
\text { нівелювати їх значення }\end{array}$ \\
\hline $\begin{array}{l}\text { Команда } \\
\text { проекту }\end{array}$ & $\begin{array}{l}\text { Якісне та своєчасне } \\
\text { виконання проекту } \\
\text { відповідно до } \\
\text { встановлених вимог }\end{array}$ & $\begin{array}{l}\text { Можливість затримки та } \\
\text { коригування основних } \\
\text { параметрів при реалізації } \\
\text { проекту. } \\
\text { Гнучкість замовника } \\
\text { (ініціатора, власника), яка } \\
\text { може призвести до } \\
\text { додаткових правок та змін }\end{array}$ & $\begin{array}{l}\text { Максимальне слідування } \\
\text { технічним вимогам, для } \\
\text { виключення зайвого } \\
\text { втручання замовника } \\
\text { (ініціатора, власника). } \\
\text { Самостійна пропозиція нових } \\
\text { ідей для проекту. } \\
\text { Попереднє обговорення } \\
\text { бажаних коригувань з метою } \\
\text { нівелювати їх значення }\end{array}$ \\
\hline Ініціатор & $\begin{array}{l}\text { Якісне та своєчасне } \\
\text { виконання проекту }\end{array}$ & $\begin{array}{l}\text { Можливість виявлення } \\
\text { неточностей основних } \\
\text { параметрів проекту. } \\
\text { Гнучкість замовника } \\
\text { (власника, інвестора), яка } \\
\text { може призвести до } \\
\text { додаткових правок та змін }\end{array}$ & $\begin{array}{l}\text { Максимально чітке } \\
\text { визначення технічних вимог }\end{array}$ \\
\hline Замовник & $\begin{array}{l}\text { Якісне та своєчасне } \\
\text { виконання проекту }\end{array}$ & $\begin{array}{l}\text { Можливість виявлення } \\
\text { неточностей основних } \\
\text { параметрів проекту. } \\
\text { Гнучкість ініціатора } \\
\text { (власника, інвестора), яка } \\
\text { може призвести до } \\
\text { додаткових правок та змін }\end{array}$ & $\begin{array}{l}\text { Максимально чітке } \\
\text { визначення технічних вимог }\end{array}$ \\
\hline Власник & $\begin{array}{l}\text { Якісне та своєчасне } \\
\text { отримання } \\
\text { результату проекту }\end{array}$ & $\begin{array}{l}\text { Можливість виявлення } \\
\text { неточностей основних } \\
\text { параметрів проекту. }\end{array}$ & $\begin{array}{l}\text { Максимально чітке } \\
\text { визначення технічних вимог }\end{array}$ \\
\hline
\end{tabular}


Продовження таблиці 3

Continuation of Table 3

\begin{tabular}{|c|c|c|c|}
\hline 1 & 2 & 3 & 4 \\
\hline & & $\begin{array}{l}\text { Гнучкість ініціатора } \\
\text { (замовника, інвестора), яка } \\
\text { може призвести до } \\
\text { додаткових правок та змін }\end{array}$ & \\
\hline Інвестор & $\begin{array}{l}\text { Якісне та своєчасне } \\
\text { виконання проекту }\end{array}$ & $\begin{array}{l}\text { Можливість виявлення } \\
\text { неточностей основних } \\
\text { параметрів проекту. } \\
\text { Несвоєчасність } \\
\text { надходження фінансових } \\
\text { ресурсів до проекту }\end{array}$ & $\begin{array}{l}\text { Максимально чітке } \\
\text { дотримання надходження } \\
\text { фінансових потоків до } \\
\text { проекту }\end{array}$ \\
\hline $\begin{array}{l}\text { Конкуренти } \\
\text { основних } \\
\text { учасників } \\
\text { проекту }\end{array}$ & $\begin{array}{l}\text { Неякісне та } \\
\text { несвоєчасне } \\
\text { виконання проекту }\end{array}$ & $\begin{array}{l}\text { Несанкційоване втручання у } \\
\text { процес планування та } \\
\text { реалізацію проекту. } \\
\text { Несвоєчасність } \\
\text { надходження фінансових } \\
\text { ресурсів до проекту. } \\
\text { Гнучкість ініціатора } \\
\text { (замовника, власника, } \\
\text { інвестора), яка може } \\
\text { призвести до додаткових } \\
\text { правок та змін }\end{array}$ & $\begin{array}{l}\text { Своєчасне блокування } \\
\text { несанкційованого доступу до } \\
\text { проекту }\end{array}$ \\
\hline Органи влади & $\begin{array}{l}\text { Якісне та своєчасне } \\
\text { виконання проекту }\end{array}$ & $\begin{array}{l}\text { Можливість виявлення } \\
\text { неточностей основних } \\
\text { параметрів проекту, які } \\
\text { можуть вплинути на } \\
\text { отримання дозволів. } \\
\text { Бездіяльність представників } \\
\text { органів влади. } \\
\text { Постійні зміни у чинному } \\
\text { законодавстві }\end{array}$ & $\begin{array}{l}\text { Чітке та своєчасне надання } \\
\text { консультацій щодо чинного } \\
\text { законодавства }\end{array}$ \\
\hline Ліцензіари & $\begin{array}{l}\text { Якісне та своєчасне } \\
\text { виконання проекту }\end{array}$ & $\begin{array}{l}\text { Можливість виявлення } \\
\text { неточностей основних } \\
\text { параметрів проекту, які } \\
\text { можуть вплинути на } \\
\text { отримання ліцензій. } \\
\text { Бездіяльність ліцензіарів. } \\
\text { Постійні зміни у чинному } \\
\text { законодавстві }\end{array}$ & $\begin{array}{l}\text { Чітке та своєчасне надання } \\
\text { консультацій щодо чинного } \\
\text { законодавства }\end{array}$ \\
\hline $\begin{array}{l}\text { Громадські } \\
\text { групи та } \\
\text { організації }\end{array}$ & $\begin{array}{l}\text { Екологічно чисте та } \\
\text { безвідходне } \\
\text { провадження } \\
\text { діяльності продукту } \\
\text { проекту }\end{array}$ & $\begin{array}{l}\text { Несанкційоване втручання у } \\
\text { процес реалізації проекту }\end{array}$ & $\begin{array}{l}\text { Постійний моніторинг та } \\
\text { контроль за станом } \\
\text { навколишнього середовища }\end{array}$ \\
\hline $\begin{array}{l}\text { Підрядники/ } \\
\text { постачальники }\end{array}$ & $\begin{array}{l}\text { Якісне та своєчасне } \\
\text { виконання умов } \\
\text { договорів } \\
\text { підряду/постачання }\end{array}$ & $\begin{array}{l}\text { Можливість виявлення } \\
\text { неточностей основних } \\
\text { параметрів проекту. }\end{array}$ & $\begin{array}{l}\text { Максимально чітке } \\
\text { дотримання умов договорів } \\
\text { підряду/постачання }\end{array}$ \\
\hline
\end{tabular}


Продовження таблиці 3

Continuation of Table 3

\begin{tabular}{|l|l|l|l|}
\hline \multicolumn{1}{|c|}{} & \multicolumn{1}{|c|}{2} & \multicolumn{1}{|c|}{3} & \multicolumn{1}{|c|}{4} \\
\hline & & $\begin{array}{l}\text { Несвоєчасність } \\
\text { надходження фінансових } \\
\text { ресурсів до проекту. } \\
\text { Несвоєчасність поставок та } \\
\text { виконання підрядних робіт } \\
\text { до проекту }\end{array}$ & \\
\hline $\begin{array}{l}\text { Iнші зацікавлені } \\
\text { сторони }\end{array}$ & $\begin{array}{l}\text { Якісне/неякісне та } \\
\text { своєчасне/несвоєчас } \\
\text { не виконання } \\
\text { проекту }\end{array}$ & $\begin{array}{l}\text { Несанкційоване втручання у } \\
\text { процес планування та } \\
\text { реалізацію проекту. }\end{array}$ & $\begin{array}{l}\text { Своєчасне блокування } \\
\text { несанкційованого доступу до } \\
\text { проекту }\end{array}$ \\
\hline $\begin{array}{l}\text { Споживачі } \\
\text { кінцевої } \\
\text { продукції }\end{array}$ & $\begin{array}{l}\text { Якісне та своєчасне } \\
\text { отримання } \\
\text { результату проекту }\end{array}$ & $\begin{array}{l}\text { Можливість виявлення } \\
\text { неточностей основних } \\
\text { параметрів проекту }\end{array}$ & $\begin{array}{l}\text { Максимально чітке } \\
\text { визначення технічних вимог }\end{array}$ \\
\hline
\end{tabular}

Виходячи із даних табл. 3 можна зрозуміти, які стратегії співпраці із стейкхолдерами запропонованого проекту необхідно обрати для успішної та своєчасної реалізації проекту.

Наступним інструментом, який можна застосувати для аналізу стейкхолдерів, $\epsilon$ їх класифікація на стейквочерів та стейкіперів [13,17,18]. Зокрема, стейквочери - групи, перед якими керівник проекту та його команда несе пряму відповідальність за успіх проекту, та стейкіпери - групи, які несуть відповідальність за результат перед більш широкими колами, за які замовник не відповідає. Зазначену класифікацію наведемо у вигляді табл. 4. літаків

Таблиця 4 - Класифікація стейкхолдерів організаційних проектів у сфері обслуговування

Table 4 - Classification of Stakeholders for Organizational Projects in the Field of Aircraft Maintenance

\begin{tabular}{|c|l|c|}
\hline Стейквочери & \multicolumn{1}{|c|}{$\begin{array}{c}\text { Стейкхолдер/ } \\
\text { група стейкхолдерів }\end{array}$} & Стейкіпери \\
\hline+ & Ініціатор & + \\
\hline+ & Замовник & + \\
\hline+ & Власник & + \\
\hline+ & Інвестор & + \\
\hline & $\begin{array}{l}\text { Конкуренти основних учасників } \\
\text { проекту }\end{array}$ & + \\
\hline & Органи влади & + \\
\hline & Ліцензіари & + \\
\hline & Громадські групи та організації \\
\hline+ & Підрядники/постачальники & \\
\hline+ & Інші зацікавлені сторони & \\
\hline & Споживачі кінцевої продукції & \\
\hline
\end{tabular}

Один й той самий стейкхолдер може бути як стейквочером, так і стейкіпером. Таке розуміння зацікавлених сторін також дає керівнику проекту та його команді додаткову інформацію щодо розроблення майбутньої стратегії.

Для більш детального аналізу стейкхолдерів можна використати ще декілька інструментів, зокрема матриці такі, як: «Влада-Динамізм», «Загрози-Співробітництво» та «Наміри/Поінформованість» $[13,15,16]$.

Матриця «Влада-Динамізм» показує можливість зміни відношення стейкхолдера до проекту, зокрема високий динамізм говорить про те, що стейкхолдер може різко змінити своє відношення на 
негативне (у випадку настання певних факторів), або, навпаки, на позитивне. Наведемо цю матрицю у вигляді табл. 5.

Таблиця 5 - Матриця «Влада-Динамізм»

Table 5 - Matrix "Power-Dynamism"

\begin{tabular}{|c|c|c|}
\hline \multirow{2}{*}{ Влада } & Високий & Низький \\
\hline & $\mathrm{A}$ & B \\
\hline Низька & $\begin{array}{l}\text { Команда проекту } \\
\text { Підрядники/постачальники } \\
\text { Споживачі кінцевої продукції }\end{array}$ & $\begin{array}{l}\text { Замовник } \\
\text { Власник } \\
\text { Інші зацікавлені сторони }\end{array}$ \\
\hline & $\mathrm{C}$ & $\mathrm{D}$ \\
\hline Висока & $\begin{array}{l}\text { Керівник проекту } \\
\text { Конкуренти основних учасників }\end{array}$ & $\begin{array}{l}\text { Ініціатор } \\
\text { Інвестор } \\
\text { Органи влади } \\
\text { Ліцензіари } \\
\text { Громадські групи та організації }\end{array}$ \\
\hline
\end{tabular}

Iз табл. 5 можна зробити висновок про те, якою є характеристика важливості зацікавлених сторін організаційного проекту у сфері обслуговування літаків, в залежності від їх положення, зокрема: зацікавлені сторони у групах А та В найбільш прості у спілкуванні; у групі C - важливі у зв'язку із тим, що у них є влада та високий динамізм, тому ця група дуже мобільна; у групі D стейкхолдери заслуговують більшої уваги тому, що вони мають владу та низький динамізм і це може призвести до проблем із реалізацією проекту.

Наступна матриця «Загрози-Співробітництво» складається із чотирьох блоків, у кожному із яких проводиться окрема робота, що спрямована на покращення взаємовідносин із стейкхолдерами.

Таблиця 6 - Матриця «Загрози-Співробітництво»

Table 6 - Matrix “The Threat-Co-operation”

\begin{tabular}{|c|c|c|}
\hline Співробітництво $\quad$ Загрози & Високі & Низькі \\
\hline 1 & 2 & 3 \\
\hline Високе & $\begin{array}{l}\text { Інвестор } \\
\text { Підрядники/постачальники }\end{array}$ & $\begin{array}{l}\text { Керівник проекту } \\
\text { Ініціатор } \\
\text { Замовник } \\
\text { Власник } \\
\text { Інші зацікавлені сторони } \\
\text { Споживачі кінцевої продукції }\end{array}$ \\
\hline Низьке & $\begin{array}{l}\text { Команда проекту } \\
\text { Конкуренти основних учасників }\end{array}$ & $\begin{array}{l}\text { Органи влади } \\
\text { Ліцензіари } \\
\text { Громадські групи та організації }\end{array}$ \\
\hline
\end{tabular}

Iз табл. 6 видно, що найбільшу увагу необхідно приділити першому блоку (високі загрози та високе співробітництво) тому, що частіше за все він включає у себе ключових стейкхолдерів проекту, у яких високий інтерес та висока влада відносно проекту. Тому керівнику проекту та його команді необхідно підтримувати співробітництво із цими стейкхолдерами та тримати їх у курсі того, що відбувається із проектом.

Одним із останніх, але не менш важливих інструментів для аналізу стейкхолдерів $є$ матриця «Наміри-Поінформованість», яку наведено у табл. 7.

Із інформації, що наведена у табл. 7 видно, що найбільшу увагу необхідно приділити об'єктам, які знаходяться у четвертому блоці, у яких немає інформації та скорше за все будуть протидіяти, ніж співпрацювати. Тому від керівника проекту та його команди вимагається постійне їх інформування та проведення робіт, що спрямовані на задоволення їх інтересів. Таким чином, їх можна буде перевести із цього блоку у інший необхідний. 
Таблиця 7 - Матриця «Наміри-Поінформованість»

Table 7 - Matrix “The Intent-Awareness"

\begin{tabular}{|c|l|l|}
\hline Поінформованість Наміри & \multicolumn{1}{|c|}{ Підтримка } & \multicolumn{1}{|c|}{ Протидія } \\
\hline \multicolumn{1}{|c|}{ Поінформований } & $\begin{array}{l}\text { Керівник проекту } \\
\text { Ініціатор } \\
\text { Власник }\end{array}$ & $\begin{array}{l}\text { Команда проекту } \\
\text { Інші зацікавлені сторони } \\
\text { Конкуренти основних учасників } \\
\text { Органи влади } \\
\text { Ліцензіари }\end{array}$ \\
\hline Не володіє інформацією & $\begin{array}{l}\text { Громадські групи та організації } \\
\text { Споживачі кінцевої продукції }\end{array}$ & $\begin{array}{l}\text { Інвестор } \\
\text { Підрядники/постачальники } \\
\text { Замовник }\end{array}$ \\
\hline
\end{tabular}

Наведене вище - це основні інструменти аналізу стейкхолдерів проекту, які допомагають керівнику проекту та його команді, з ким та яким чином треба працювати у рамках проекту.

Як підсумок, на підставі проведено аналізу керівник проекту та його команда повинні розробити стратегії взаємодії із стейкхолдерами протягом всього проекту.

По-перше, необхідно розробити схему стратегії комунікації зі стейкхолдерами організаційного проекту у сфері обслуговування літаків, яку представимо у вигляді табл. 8.

Таблиця 8 - Схема стратегії комунікації зі стейкхолдерами

Table 8 - Scheme of Communication Strategy with Stakeholders

\begin{tabular}{|l|l|l|}
\hline \multicolumn{1}{|c|}{ Тип } & \multicolumn{1}{|c|}{ Стратегія } & \multicolumn{1}{|c|}{ Стейкхолдер/група стейкхолдерів } \\
\hline Важливий & Повністю задовольняти вимоги & Команда проекту \\
& & Підрядники/постачальники \\
\hline Ключові & Управління & Менеджер проекту \\
& & Власник \\
& Ініціатор \\
\hline Залучені & Інформувати & Замовник \\
& & Інвестор \\
& & Органи влади \\
& & Ліцензіари \\
& Споживачі кінцевої продукції \\
\hline Інші & Моніторинг & Конкуренти основних учасників проекту \\
& & Громадські групи та організації \\
& & Інші зацікавлені сторони \\
\hline
\end{tabular}

Iз табл. 8 видно, яким чином розподілені стейкхолдери за типом та стратегіями, які команда проекту буде застосовувати до них.

Наступним кроком буде складення підсумкової таблиці, яка допоможе якісно управляти стейкхолдерами протягом усього життєвого циклу проекту, що наведена у вигляді табл. 9. літаків

Таблиця 9 - План управління стейкхолдерами організаційного проекту у сфері обслуговування Aircraft

Table 9 - Plan of Management of Stakeholders of an Organizational Project in the Field of Servicing

\begin{tabular}{|c|l|l|l|c|}
\hline $\begin{array}{c}\text { Стейкхолдер/група } \\
\text { стейкхолдерів }\end{array}$ & \multicolumn{1}{|c|}{ Інтерес } & $\begin{array}{c}\text { Тактика } \\
\text { комунікації }\end{array}$ & $\begin{array}{c}\text { Формат } \\
\text { повідомлення }\end{array}$ & $\begin{array}{c}\text { Частота } \\
\text { надання } \\
\text { інформації }\end{array}$ \\
\hline 1 & \multicolumn{1}{|c|}{2} & 3 & 4 & 5 \\
\hline Менеджер проекту & $\begin{array}{l}\text { Якісне та своєчасне } \\
\text { виконання проекту } \\
\text { відповідно до } \\
\text { встановлених вимог }\end{array}$ & $\begin{array}{l}\text { Особисте/ } \\
\text { онлайн } \\
\text { взаємодія }\end{array}$ & Формальний & $\begin{array}{l}\text { Постійна } \\
\text { взаємодія }\end{array}$ \\
\hline
\end{tabular}


Продовження таблиці 9

Continuation of Table 9

\begin{tabular}{|c|c|c|c|c|}
\hline 1 & 2 & 3 & 4 & 5 \\
\hline Команда проекту & $\begin{array}{l}\text { Якісне та своєчасне } \\
\text { виконання проекту } \\
\text { відповідно до } \\
\text { встановлених вимог }\end{array}$ & $\begin{array}{l}\text { Онлайн } \\
\text { взаємодія }\end{array}$ & Формальний & $\begin{array}{l}\text { Постійна } \\
\text { взаємодія }\end{array}$ \\
\hline Ініціатор & $\begin{array}{l}\text { Якісне та своєчасне } \\
\text { виконання проекту }\end{array}$ & $\begin{array}{l}\text { Онлайн } \\
\text { взаємодія }\end{array}$ & Неформальний & $\begin{array}{l}\text { Постійна } \\
\text { взаємодія }\end{array}$ \\
\hline Замовник & $\begin{array}{l}\text { Якісне та своєчасне } \\
\text { виконання проекту }\end{array}$ & $\begin{array}{l}\text { Онлайн } \\
\text { взаємодія }\end{array}$ & Неформальний & $\begin{array}{l}\text { Постійна } \\
\text { взаємодія }\end{array}$ \\
\hline Власник & $\begin{array}{l}\text { Якісне та своєчасне } \\
\text { отримання результату } \\
\text { проекту }\end{array}$ & $\begin{array}{l}\text { Онлайн } \\
\text { взаємодія }\end{array}$ & Неформальний & $\begin{array}{l}\text { Постійна } \\
\text { взаємодія }\end{array}$ \\
\hline Інвестор & $\begin{array}{l}\text { Якісне та своєчасне } \\
\text { виконання проекту }\end{array}$ & $\begin{array}{l}\text { Онлайн } \\
\text { взаємодія }\end{array}$ & Формальний & $\begin{array}{l}\text { Постійна } \\
\text { взаємодія }\end{array}$ \\
\hline $\begin{array}{l}\text { Конкуренти } \\
\text { основних учасників } \\
\text { проекту }\end{array}$ & $\begin{array}{l}\text { Неякісне та несвоєчасне } \\
\text { виконання проекту }\end{array}$ & $\begin{array}{l}\text { Особисте/ } \\
\text { онлайн } \\
\text { взаємодія }\end{array}$ & Неформальний & Щокварталу \\
\hline Органи влади & $\begin{array}{l}\text { Якісне та своєчасне } \\
\text { виконання проекту }\end{array}$ & Особисте & Формальний & $\begin{array}{l}\text { За наявності } \\
\text { потреби }\end{array}$ \\
\hline Ліцензіари & $\begin{array}{l}\text { Якісне та своєчасне } \\
\text { виконання проекту }\end{array}$ & Особисте & Формальний & $\begin{array}{l}\text { За наявності } \\
\text { потреби }\end{array}$ \\
\hline $\begin{array}{l}\text { Громадські групи та } \\
\text { організації }\end{array}$ & $\begin{array}{l}\text { Екологічно чисте та } \\
\text { безвідходне провадження } \\
\text { діяльності продукту } \\
\text { проекту }\end{array}$ & $\begin{array}{l}\text { Онлайн } \\
\text { взаємодія }\end{array}$ & Формальний & Щокварталу \\
\hline $\begin{array}{l}\text { Підрядники/ } \\
\text { постачальники }\end{array}$ & $\begin{array}{l}\text { Якісне та своєчасне } \\
\text { виконання умов договорів } \\
\text { підряду/постачання }\end{array}$ & $\begin{array}{l}\text { Особисте/ } \\
\text { онлайн } \\
\text { взаємодія }\end{array}$ & Формальний & $\begin{array}{l}\text { Постійна } \\
\text { взаємодія }\end{array}$ \\
\hline $\begin{array}{l}\text { Інші зацікавлені } \\
\text { сторони }\end{array}$ & $\begin{array}{l}\text { Якісне/неякісне та } \\
\text { своєчасне/несвоєчасне } \\
\text { виконання проекту }\end{array}$ & $\begin{array}{l}\text { Онлайн } \\
\text { взаємодія }\end{array}$ & Формальний & Щокварталу \\
\hline $\begin{array}{l}\text { Споживачі кінцевої } \\
\text { продукції }\end{array}$ & $\begin{array}{l}\text { Якісне та своєчасне } \\
\text { отримання результату } \\
\text { проекту }\end{array}$ & $\begin{array}{l}\text { Онлайн } \\
\text { взаємодія }\end{array}$ & Формальний & Щомісяця \\
\hline
\end{tabular}

У табл. 9 наведено план управління стейкхолдерами, а також яким чином будуть відбуватися із ними комунікації.

Окрім ідентифікації та планування управління стейкхолдерами команді організаційного проекту у сфері обслуговування літаків необхідно приділити увагу ще й виявленню ризиків, що пов’язані із стейкхолдерами, та управлінню ними.

\section{Висновки.}

За результатами даного дослідження була отримана попередня інформація про стейкхолдерів організаційного проекту у сфері обслуговування літаків щодо їх ідентифікації та оцінки їхнього впливу (позитивного або негативного).

Результати попередньої ідентифікації стейкхолдерів надає керівнику проекту та його команді інструменти для управління ними.

Крім того, можна дійти висновку, що означена тематика $є$ актуальною та потребує проведення подальших досліджень організаційних проектів у сфері обслуговування літаків.

\section{ПЕРЕЛІК ПОСИЛАНЬ}

1. Вайсман, В. О. Моделі, методи та механізми створення і функціонування проектнокерованої організації : автореф. дис. ... д-ра техн. наук : 05.13.22 / Вайсман Владислав Олександрович; Одес. нац. морс. ун-т. - О., 2010. - 35 с. 
2. Чернов, С. К. Ефективні організаційні структури в управлінні програмами розвитку наукомістких підприємств: автореф. дис... д-ра техн. наук : 05.13.22 / Чернов Сергій Костянтинович; Нац. ун-т кораблебудування ім. адмірала Макарова. - Миколаїв, 2007. - 43 с.

3. Годованюк, П. Д. Моделі, алгоритми та стратегії в проектах вдосконалення дорожньобудівельної техніки: автореф. дис... канд. техн. наук : 05.13.22 / Годованюк Петро Дмитрович; Нац. транспорт. ун-т. - К., 2006. - 19 с.

4. Марков, О. Д. Формування послуги автосервісу / О. Д. Марков, В. В. Низковолосов // Збірник Національного транспортного університету. - К. : НТУ, 2014. - Вип. 30. - С. 234-245.

5. Емад, А. Р. Методологічні основи формування, аналізу та управління програмою розвитку авіаційної техніки: автореф. дис... д-ра техн. наук : 05.13.22 / А. Абдуль Рета Емад; Нац. аерокосм. унт ім. М.Є.Жуковського "Харк. авіац. ін-т". - Х., 2006. - 33 с.

6. Сляднєв, О. В. Управління проектами створення модифікацій пасажирських і транспортних літаків в умовах ринкової економіки: автореф. дис... канд. техн. наук : 05.13.22 / Сляднєв Олег Всеволодович ; ВАТ "Укр. НДІ авіац. технології" (УкрНДІАТ). - К., 2004. - 18 с.

7. Бушуев, С. Д. Модели и методы стратегического развития быстрорастущих организаций / С. Д. Бушуев, Н. С. Бушуева, А. М. Захаров // Управління проектами та розвиток виробництва: Зб. наук. пр. - Луганськ : вид-во СНУ ім. В. Даля, 2006. - № 1(17). - С. 5-13.

8. Данченко, О. Б. Креативний потенціал команди як фактор успіху проекту / О. Б. Данченко, Ю. М. Кузьмінська // Управління проектами та розвиток виробництва: Зб.наук.пр. - Луганськ : вид-во СНУ ім. В. Даля, 2012. - № 3 (43). - С. 70-74.

9. Freeman, R. E. Strategic management: A Stakeholder approach. - Boston: Pitman, 1984.

10. Гусєва, Ю. Ю. Управління зацікавленими сторонами освітніх проектів [Електронний ресурс] / Ю. Ю. Гусєва, М. В. Сидоренко, І. В. Чумаченко // Вісник Національного технічного університету "ХПІ". Серія : Стратегічне управління, управління портфелями, програмами та проектами. [Електронний ресурс]. - 2016. - № 2. - С. 8-12. - Режим доступу: http://nbuv.gov.ua/UJRN/vntux_ctr_2016_2_4. - Назва з екрану.

11. Сепеда Гуаман, Діего Фернандо. Організаційні проекти у сфері обслуговування літаків / Діего Фернандо Сепеда Гуаман // Управління проектами: стан та перспективи (11.09-14.09.2018) : матеріали XIV міжнар. наук.-практ. конф. / Мін-во освіти та науки України, Національний університет кораблебудування ім. адмірала Макарова. - Миколаїв : НУК, 2018. - с. 40.

12. Сепеда Гуаман, Діего Фернандо. Особливості управління організаційними проектами у сфері обслуговування літаків / Діего Фернандо Сепеда Гуаман // Вісник ЧДТУ. Серія: Технічні науки. - 2018. - № 3. - С. 34-41.

13. Применение теории стейкхолдеров при продвижении проектов в интернете [Электронный pecypc] // Cossa : Интернет-сайт / Cossa.ru. - Режим доступа: https://www.cossa.ru/152/198318/. Название с экрана. - Дата обращения: 28.09.2018.

14. A Guide to the Project Management Body of Knowledge (PMBOK® Guide) - Six Edition. USA. - PMI, 2017. - $574 \mathrm{p}$.

15. ISO 26000:2010 Guidance on social responsibility [Electronic resource] // International Organization for Standardization : Web-site / International Organization for Standardization. - Mode of access: https://www.iso.org/standard/42546.html. - Title from Screen. - Date of Access: 28 September 2018.

16. AA1000 Stakeholder Engagement Standard (SES) 2018 [Electronic resource] // AccountAbility : Web-site / AccountAbility. - Mode of access: http://www.accountability.org/standards/. - Title from Screen. Date of Access: 28 September 2018.

17. Финогеева, А. И. Совершенствование механизма взаимодействия компании с заинтересованными сторонами [Электронный ресурс] / А. И. Финогеева // УЭкС. - 2017. - № 3 (97). Режим доступа: https://cyberleninka.ru/article/n/sovershenstvovanie-mehanizma-vzaimodeystviyakompanii-s-zainteresovannymi-storonami. - Название с экрана.

18. Нохріна Л. А. Алгоритм ідентифікації стейкхолдерів / Л. А. Нохріна // Місто. Культура. Цивілізація (квітень 2015) : матеріали V міжнар. наук.-теор. Інтернет-конф. / Мін-во освіти та науки України, ХНУМГ ім. О. М. Бекетова. - Харків: ХНУМГ ім. О. М. Бекетова, 2015. - с. 168-175.

\section{REFERENCES}

1. Vaysman V.O. (2010) Modeli, metody ta mekhanizmy stvorennya i funktsionuvannya proektnokerovanoyi orhanizatsiyi. Avtoreferat Dys. [Models, methods and mechanisms of creation and functioning of a project-managed organization. Author's abstract.]. Odesa, 35. [in Ukrainian]. 
2. Chernov S.K. (2007) Efektyvni orhanizatsiyni struktury v upravlinni prohramamy rozvytku naukomistkykh pidpryyemstv. Avtoreferat Dys. [Effective organizational structures in the management of programs for the development of high-tech enterprises. Author's abstract.]. Mykolayiv, 43. [in Ukrainian].

3. Hodovanyuk P.D. (2006) Modeli, alhorytmy ta stratehiyi v proektakh vdoskonalennya dorozhn'obudivel'noyi tekhniky. Avtoreferat Dys. [Models, algorithms and strategies in projects of improvement of road-building machinery. Author's abstract.]. K., 19. [in Ukrainian].

4. Markov O.D., Nyzkovolosov V.V. (2014) Formuvannya posluhy avtoservisu [Formation of car service]. Zbirnyk Natsional'noho transportnoho universytetu. [Proceedings of the National Transport University], 30, 234-245. [in Ukrainian].

5. Emad A.R. (2006) Metodolohichni osnovy formuvannya, analizu ta upravlinnya prohramoyu rozvytku aviatsiynoyi tekhniky. Avtoreferat Dys. [Methodological bases of formation, analysis and management of aviation engineering program. Author's abstract.]. Kharkiv, 33. [in Ukrainian].

6. Slyadnev O.V. (2004) Upravlinnya proektamy stvorennya modyfikatsiy pasazhyrs'kykh i transportnykh litakiv v umovakh rynkovoyi ekonomiky. Avtoreferat Dys. [Management of projects for the creation of modifications of passenger and transport aircraft in a market economy. Author's abstract.]. K., 18. [in Ukrainian].

7. Bushuyev S.D., Bushueva N.S., Zakharov A.M. (2006) Modeli i metody strategicheskogo razvitiya bystrorastushchikh organizatsiy [Models and methods of strategic development of fast-growing organizations]. Upravlinnya proektamy ta rozvytok vyrobnytstva: Zb. nauk. pr. [Project management and production development: Collection of scientific works], 1.17, 5-13. [in Russian].

8. Danchenko O.B., Kuzminskaya Yu.M. (2012) Kreatyvnyy potentsial komandy yak faktor uspikhu proektu [Creative potential of the team as a factor of project success]. Upravlinnya proektamy ta rozvytok vyrobnytstva: Zb. nauk. pr. [Project management and production development: Collection of scientific works], 3.43, 70-74. [in Ukrainian]. English].

9. Freeman R.E. (1984) Strategic management: A Stakeholder approach. Boston: Pitman. [in

10. Guseva Yu.Yu., Sidorenko M.V., Chumachenko I.V. (2016) Upravlinnya zatsikavlenymy storonamy osvitnikh proektiv (Management of Stakeholders of Educational Projects). Visnyk Natsional'noho tekhnichnoho universytetu "KHPI". Seriya : Stratehichne upravlinnya, upravlinnya portfelyamy, prohramamy ta proektamy, 2, 8-12. [Electronic resource]. - Available at: http://nbuv.gov.ua/UJRN/vntux_ctr_2016_2_4. (Accessed 28 September 2018). [in Ukrainian].

11. Sepeda Huaman Dieho Fernando. Orhanizatsiyni proekty u sferi obsluhovuvannya litakiv [Organizational projects in the field of aircraft maintenance]. Materialy XIV mizhnarodnoyi naukovopraktychnoyi konferentsiyi "Upravlinnya proektamy: stan ta perspektyvy (11.09-14.09.2018)" [Materials of the XIV Int. Scientific and Practical Conf. "Project Management: Status and Prospects"]. Mykolayiv, 2018, p. 40. [in Ukrainian].

12. Sepeda Huaman Dieho Fernando. Osoblyvosti upravlinnya orhanizatsiynymy proektamy u sferi obsluhovuvannya litakiv [Features of management of organizational projects in the field of aircraft maintenance]. Visnyk Cherkas'koho derzhavnoho tekhnolohichnoho universytetu. Seriya: Tekhnichni nauky. [Bulletin of Cherkasy State Technological University. Series: Engineering], 2018, no. 3, p. 34-41. [in Ukrainian].

13. Application of the theory of stakeholders in the promotion of projects on the Internet - Cossa.ru. [Electronic resource]. - Available at: https://www.cossa.ru/152/198318/. (Accessed 28 September 2018). [in Russian].

14. A Guide to the Project Management Body of Knowledge (PMBOK® Guide) - Six Edition. (2017) USA. PMI, 574. [in Russian].

15. ISO 26000:2010 Guidance on social responsibility. International Organization for Standardization. [Electronic resource]. - Available at: https://www.iso.org/standard/42546.html. (Accessed 28 September 2018). [in English].

16. AA1000 Stakeholder Engagement Standard (SES) 2018. AccountAbility. [Electronic resource]. Available at: http://www.accountability.org/standards/. (Accessed 28 September 2018). [in English].

17. Finogeeva A.I. (2017) Sovershenstvovaniye mekhanizma vzaimodeystviya kompanii s zainteresovannymi storonami (Improvement of the mechanism of interaction of the company with interested parties). UEkS, 3.97. [Electronic resource]. - Available at: https://cyberleninka.ru/article/n/sovershenstvovanie-mehanizma-vzaimodeystviya-kompanii-szainteresovannymi-storonami. (Accessed 28 September 2018). [in Russian]. 
18. Nokhrina L.A. (2015) Alhorytm identyfikatsiyi steykkholderiv [Algherithm for identification of stakeholders]. Materialy V mizhnarodnoyi naukovo-teoretychnoyi Internet-konferentsiyi "Misto. Kul'tura. Tsyvilizatsiya (kviten' 2015)" [Materials of International Scientific and Theoretical Internet Conference "City. Culture. Civilization"]. Kharkiv, 168-175. [in Ukrainian].

\section{РЕФЕРАТ}

Мельниченко O.I. Ідентифікація стейкхолдерів організаційних проектів у сфері обслуговування літаків / О.І. Мельниченко, Д.Ф. Сепеда Гуаман, О.І. Бєлова // Вісник Національного транспортного університету. Серія «Технічні науки». Науково-технічний збірник. - К.: НТУ, 2019. Вип. 1 (43).

У статті наведено результати ідентифікації стейкхолдерів організаційних проектів у сфері обслуговування літаків із врахуванням оцінки їх впливу на проекти (негативного та позитивного). Результати ідентифікації стейкхолдерів у подальшому дозволять керівнику проекту та його команді врахувати їх для вироблення дієвих інструментів й механізмів управління стейкхолдерами.

Мета роботи - виділення стейкхолдерів організаційних проектів у сфері обслуговування літаків, проведення їх ідентифікації та оцінки їх впливу з метою задоволення їх інтересів, а також забезпечення належного рівня цінності майбутнього продукту проекту.

Методи дослідження - системний аналіз, експертна та статистична оцінка процесу управління організаційними проектами у сфері обслуговування літаків.

Швидкі темпи розвитку галузі літакобудування на сьогоднішній день вимагають від компанійвиробників удосконалення авіаційної техніки, що у свою чергу призводить до потреби своєчасного оновлення матеріально-технічної бази та обладнання для забезпечення якісного надання послуг із їх технічного обслуговування будь-де за межами виробничих потужностей заводів. Якісне технічне обслуговування повітряних суден у подальшому може забезпечити задоволення очікувань стейкхолдерів організаційних проектів у сфері обслуговування літаків. Крім того, для задоволення потреб стейкхолдерів керівникам цих проектів необхідно взяти до уваги ризики, що можуть бути пов'язані із ними та мати, як позитивні, так і негативні наслідки для цих проектів. Тому необхідно враховувати мінливість зовнішнього та внутрішнього оточення організаційних проектів у сфері обслуговування літаків, відношення самих стейкхолдерів до цих проектів можуть стати загрозою для успішної реалізації проекту та забезпечення цінностей усіх його стейкхолдерів.

Проведена попередня оцінка стейкхолдерів організаційних проектів у сфері обслуговування літаків спрямована на врахування їх впливу як позитивного, так і негативного, у процесі планування й реалізації цих проектів. Врахування цієї інформації надає змогу керівнику проекту та його команді забезпечити якісну та своєчасну реалізацію цього проекту, а також задовольнити потреби стейкхолдерів.

КЛЮЧОВІ СЛОВА: ПРОЕКТНИЙ ПІДХІД, ОРГАНІЗАЦІЙНІ ПРОЕКТИ, ОБСЛУГОВУВАННЯ ЛІТАКІВ, СТЕЙКХОЛДЕРИ, ІДЕНТИФІКАЦІЯ, ОЦІНКА ВПЛИВУ.

ABSTRACT
Melnichenko O.I., Cepeda Guaman D.F., Bielova O.I. Identification of stakeholders of organizational projects in the field of maintenance of aircraft. Visnyk National Transport University. Series «Technical sciences». Scientific and Technical Collection. - Kyiv: National Transport University, 2019. - Issue 1 (43).

The article presents the results of the identification of stakeholders of organizational projects in the field of aircraft servicing, taking into account the assessment of their impact on projects (negative and positive). The results of the identification of stakeholders in the future will allow the project manager and his team to take them into account in order to develop effective tools and mechanisms for managing stakeholders.

The purpose of the work is to highlight the stakeholders of organizational projects in the field of aircraft maintenance, to identify them and assess their impact in order to meet their interests, as well as to ensure an appropriate level of value for the future product of the project.

Research methods - system analysis, expert and statistical evaluation of the management process of organizational projects in the field of aircraft maintenance.

The rapid pace of development of the aircraft industry today requires manufacturers to improve aircraft technology, which in turn leads to the need for timely updates of the material and technical base and equipment to ensure the quality of services for their maintenance anywhere outside the production facilities. High-quality aircraft maintenance can further ensure that the stakeholders' expectations of organizational projects in the field of aircraft maintenance are met. In addition, to meet the needs of stakeholders, managers 
of these projects need to pay attention to the risks that may be associated with them and have both positive and negative consequences for these projects. Therefore, it is necessary to take into account the variability of the external and internal environment of organizational projects in the field of aircraft maintenance, the attitude of the stakeholders themselves to these projects can be a threat to the successful implementation of the project and ensuring the values of all its stakeholders.

The preliminary assessment of stakeholders of organizational projects in the field of aircraft maintenance is aimed at taking into account their influence, both positive and negative, in the process of planning and implementing these projects. Accounting for this information enables the project manager and his team to ensure the high-quality and timely implementation of this project, as well as to meet the needs of stakeholders.

KEYWORDS: PROJECT APPROACH, ORGANIZATIONAL PROJECTS, MAINTENANCE OF AIRPLANES, STEAKHOLDERS, IDENTIFICATION, EVALUATION OF INFLUENCE.

\section{PЕФЕРАТ}

Мельниченко А.И. Идентификация стейкхолдеров организационных проектов в сфере обслуживания самолетов / А.И. Мельничекно, Д.Ф. Сепеда Гуаман, Е.И. Белова // Вестник Национального транспортного университета. Серия «Технические науки». Научно-технический сборник. - К.: НТУ, 2019. - Вып. 1 (43).

В статье представлены результаты идентификации стейкхолдеров организационных проектов в сфере обслуживания самолетов с учетом оценки их влияния на проекты (отрицательного и положительного). Результаты идентификации стейкхолдеров в дальнейшем позволят руководителю проектов и его команде учесть их для разработки действенных инструментов и механизмов управления стейкхолдерами.

Цель работы - выделение стейкхолдеров организационных проектов в сфере обслуживания самолетов, проведение их идентификации и оценки их влияния с целью удовлетворения их интересов, а также обеспечение надлежащего уровня ценности будущего продукта проекта.

Методы исследования - системный анализ, экспертная и статистическая оценка процесса управления организационными проектами в сфере обслуживания самолетов.

Быстрые темпы развития отрасли самолетостроения на сегодняшний день требуют от компаний-производителей усовершенствования авиационной техники, что в свою очередь приводит к потребности своевременного обновления материально-технической базы и оборудования для обеспечения качественного предоставления услуг по их техническому обслуживанию в любом месте за пределами производственных мощностей заводов. Качественное техническое обслуживание воздушных суден в дальнейшем может обеспечить удовлетворение ожиданий стейкхолдеров организационных проектов в сфере обслуживания самолетов. Кроме того, для удовлетворения потребностей стейкхолдеров руководителям этих проектов необходимо обратить внимание на риски, которые могут быть связаны с ними и иметь, как положительные, так и негативные последствия для этих проектов. Поэтому необходимо учитывать изменчивость внешнего и внутреннего окружения организационных проектов в сфере обслуживания самолетов, отношение самих стейкхолдеров к этим проектам может стать угрозой для успешной реализации проекта и обеспечения ценностей всех его стейкхолдеров.

Проведенная предварительная оценка стейкхолдеров организационных проектов в сфере обслуживания самолетов направлена на учет их влияния как положительного, так и отрицательного, в процессе планирования и реализации этих проектов. Учет этой информации дает возможность руководителю проекта и его команде обеспечить качественную и своевременную реализацию этого проекта, а также удовлетворить потребности стейкхолдеров.

КЛЮЧЕВЫЕ СЛОВА: ПРОЕКТНЫЙ ПОДХОД, ОРГАНИЗАЦИОННЫЕ ПРОЕКТЫ, ОБСЛУЖИВАНИЕ САМОЛЕТОВ, СТЕЙКХОЛДЕРЫ, ИДЕНТИФИКАЦИЯ, ОЦЕНКА ВЛИЯНИЯ.

\section{АВТОРИ:}

Мельниченко Олександр Іванович, кандидат технічних наук, професор, вчений секретар, Національний транспортний університет, e-mail: melnichenko@ntu.edu.ua, Україна, 01010, м. Київ, вул. М. Омеляновича-Павленка, 1, к. 209a, orcid.org/0000-0001-9694-9824.

Сепеда Гуаман Діего Фернандо, Університет «КРОК», e-mail: ferchoevol2@hotmail.com, Україна, 03113, м. Київ, вул. Табірна, 30-32, orcid.org/0000-0003-0791-6532. 
Бєлова Олена Ігорівна, кандидат економічних наук, доцент кафедри бізнес-адміністрування та управління проектами, Університет «КРОК», e-mail: belovaelenag@gmail.com, Україна, 03113, м. Київ, вул. Табірна, 30-32, orcid.org/0000-0001-9359-6947.

\section{AUTHOR:}

Melnichenko Olexander Ivanovich, Candidate of Technical Science, professor, academic secretary, National Transport University, Kyiv, Ukraine, e-mail: melnichenko@ntu.edu.ua, Ukraine, 01010, Kyiv, Omeljanovicha-Pavlenka str. 1, Of. 209a, orcid.org/0000-0001-9694-9824.

Cepeda Guaman Diego Fernando, University “KROK”, e-mail: ferchoevol2@hotmail.com, Ukraine ,03113, Kyiv, Tabirna St, 30-32, orcid.org/0000-0003-0791-6532.

Bielova Olena Ihorivna, Candidate of Economic Science, associate professor, department of the business administration and project management, University "KROK", e-mail: belovaelenag@gmail.com, Ukraine ,03113, Kyiv, Tabirna St, 30-32, orcid.org/0000-0001-9359-6947.

\section{AВТОРЫ:}

Мельниченко Александр Иванович, кандидат технических наук, профессор, Ученый секретарь, Национальный транспортный университет, Украина, 01010, г. Киев, ул. М. Омелянович-Павленко, 1, к. 209a, e-mail: melnichenko@ntu.edu.ua, orcid.org/0000-0001-9694-9824.

Сепеда Гуаман Диего Фернандо, Университет «КРОК», e-mail: ferchoevol2@hotmail.com, Украина, 03113, г. Киев, ул. Лагерная, 30-32, orcid.org/0000-0003-0791-6532.

Белова Елена Игоревна, кандидат экономических наук, доцент, кафедра бизнесадминистрирования и управления проектами, Университет «КРОК», e-mail: belovaelenag@gmail.com, Украина, 03113, г. Киев, ул. Лагерная, 30-32, orcid.org/0000-0001-9359-6947.

\section{РЕЦЕНЗЕНТИ:}

Прокудін Г.С., доктор технічних наук, професор, завідувач кафедри "Міжнародних перевезень та митного контролю" Національного транспортного університету, Київ, Україна.

Петрова І.Л., доктор економічних наук, професор, завідувач кафедри маркетингу та поведінкової економіки Університету «КРОК», Київ, Україна.

\section{REVIEWER:}

Prokudin G.S., Doctor of Technical Sciences, Professor, Head of the Department for International Transportation and Customs Control, National Transport University, Kyiv, Ukraine.

Petrova I.L., Doctor of Economics Sciences, Professor, Head of The Department of Marketing and Behavioral Economics, University «KROK», Kyiv, Ukraine. 